Nutrition at Wye College, has been appointed to the chair of horticulture at that College from October I, 1965. Prof. R. A. J. Coutrez, "Professeur extraordinaire" at the Free University of Brussels and astronomer at the Royal Observatory of Belgium, has been appointed Belgian Visiting Professor for the session 1964-65.

Oxford

The annual report of the Curators of the Bodleian Library for the year ended. July 31, 1963, refers to the completion of the structural work on Duke Humfrey's Library early in 1963 (Supplement No. 9 to the University Gazette, May 1964. Pp. 43. Oxford: The University, 1964. 2s.). Attention is directed to the progress of development and rearrangements which will greatly increase the efficient administration of the Library and provide space for 24 more readers, if alternative exhibition rooms are found in the Divinity School and the Proscholium is converted into a new entrance hall serving both the Divinity School and the Old Library. The annual grant from the University General Fund was $£ 221,644$, nearly $£ 9,000$ less than the previous year; but the 107,071 books and manuscripts fetched for readers and 28,653 for staff represents an increase of more than 20,000. Accessions to the Department of Printed Books totalled 44,826 volumes and 121,276 parts, compared with 44,203 and 115,844 , respectively, in the previous year.

\section{The Royal Society and Nuffield Foundation Common- wealth Bursaries Scheme}

Awards under the Royal Society and Nuffield Foundation Commonwealth Bursaries Scheme have been made as follows: Dr. Margaret C. Anderson, Botany School, Cambridge, to enable her to work on light penetration at various levels in pine forest in the Section of Agricultural Physics, C.S.I.R.O. Division of Plant Industry, Canberra, for about five months from November 1964 ; Dr. R. L. W. Averill, senior research officer, New Zealand Medical Research Council's Department of Endocrinology Research, to assist him to learn techniques of hypothalamic investigation at Oxford, for ten months during 1964-65; Dr. D. J. Eve, lecturer in chemistry, University College of Rhodesia and Nyasaland, to enable him to carry out research on the spectroscopic characterization of inorganic co-ordination compounds at Southampton, from September 1964 until June 1965; Dr. K. M. King, associate professor, Soils Department, Ontario Agricultural College, to enable him to study in the field of mierometeorology and evaporation at the C.S.I.R.O. Division of Meteorological Physics, Molbourne, for five months from December. Dr. Alicja M. Kirkien-Konasiewicz, lecturer in chemical engineering, University of the West Indies (Trinidad), to enable her to learn techniques in highresolution mass spectrometry at University College, London, from January until April 1965; Dr. S. E. Livingstone, associate professor of inorganic chemistry, University of New South Wales, to assist him to work in the field of co-ordination chemistry at University College, London, for nine months from September; Dr. B. Morris, Professorial Fellow, Department of Experimental Pathology, Australian National University, Canberra, to enable him to investigate at Oxford the role of the lymphatic system in the absorption of fat in fishes, for six months from September; Prof. K. C. Mukherji, professor of electrical engineering, Indian Institute of Technology, Bombay, to enable him to carry out investigations on electrical machines at the University of London King's College, for a year from October; Prof. R. A. Royment, professor of geology, University of Tbadan, to assist him to study the ostracods of the marine Tertiary of Australia, for three months in the autumn; Dr. G. G. E. Scudder, assistant professor of zoology, University of British Columbia, to enable him to acquire knowledge of type material of Rhyparochrominae and techniques for insect blood analysis at the Imperial College of Science and Technology, London, for a year during 1964-65; Dr. R. L. Stanton, senior lecturer in geology, University of New England, to enable him to examine naturally deformed sulphide ores, at Imperial College of Science and Technology, London, and Durham, from September until November, in connexion with investigations on the significance of surface tensions in the final development of grain shapes in such ores. Dr. L. B. Thrower, senior lecturer in botany, and Mrs. S. L. Thrower, senior demonstrator in botany, both of the University of Melbourne, to assist them in their investigations on the effect of sporulation on the pattern of movement of nutrients in fungal hyphr at Birkbeck College, London, and to attend a course on radiobiology, and to enable her to investigate the physiology of lichen growth at Birkbeck College and the British Museum (Natural History) during 1965 .

\section{Announcements}

Prof. F. G. Young, Sir William Dunn professor of biochemistry in the University of Cambridge, has been appointed the first Master of the nowly formed postgraduate Darwin College at Cambridge. Prof. Young is president of Section I (Physiology and Biochemistry) at the Southampton meeting of the British Association for the Advancement of Science (see p. 952 of this issue of Nature).

Av index to the survey Manchester and its Region, prepared for the British Association meeting held in Manchester in 1962 (Nature, 195, 890; 1962) has now been compiled by the Manchester and District Division of the Association of Assistant Librarians under the editorship of Mr. M. J. Harkin. To the public spirit of him and his colleagues warm thanks are due from all who appreciate the merits of the admirable survey originally issued for the British Association by the Local Committee.

THE fourth Louis Rapkine Memorial Lecture entitled "La Proliferation et Differenciation des Cellules Hematopoietiques" will be delivered by Dr. Louis Siminovitch (Ontario Cancer Research Institute) at the Pasteur Institute, Paris, on October 7.

A CONFEREnce on "Electron Emission", arranged by the Electronics Group of the Institute of Physics and the Physical Society, will be held in the University of Keele during October 1-2. During the conference, the Guthrie Lecture for 1964 will be delivered by Prof. Martin Ryle. Further information can be obtained from the Administration Assistant, the Institute of Physics and the Physical Society, 47 Belgrave Square, London, S.W.1.

Tre National Conference of Food Hygiene, organized by the Institute of Nutrition, Budapest, will be held in Budapest during October 29-31. Topics under consideration will include: the effect of extraneous substances in food on the human organism; the hygiene problems of pesticide residues; the hygiene problems of contaminants of technical origin (metals, plastics). Further information can be obtained from the Institute of Nutrition, Gyáli ut $3 / a$, Budapest IX.

THE annual meeting of the American Documentation Institute on "Parameters of Information Science" will be held in Philadelphia during October 5-8. Subjects under consideration will include: symbolization and transformation of information; information-seeking behaviour; information in decision procedures; analysis, correlation and indexing; document media, storage and display; memory organization and search; information sciences; goals in education; the profession; information centres and networks. Further information can be obtained from A. W. Speakman, American Documentation Institute, 2000 P Street, N.W., Washington, D.C. 20036. 